Prospects for Payments for Ecosystem Services in the Brazilian Pantanal: A Scenario Analysis

Christopher Schulz

University of Edinburgh, James Hutton Institute, Aberdeen, and Scotland's Rural College

(SRUC), Edinburgh

Antônio A. R. Ioris

University of Edinburgh

Julia Martin-Ortega

James Hutton Institute, Aberdeen

Klaus Glenk

Scotland's Rural College (SRUC), Edinburgh

\title{
Acknowledgements
}

The authors wish to thank the insightful comments and helpful criticism of three anonymous referees. In addition, they would like to thank several experts on the Pantanal who agreed to be contacted and interviewed. 


\section{Abstract \\ Prospects for Payments for Ecosystem Services in the Brazilian Pantanal: A Scenario \\ Analysis}

The present study investigates the prospects for a large-scale implementation of Payments for Ecosystem Services (PES) schemes in the Brazilian Pantanal wetland. Despite increasing environmental threats associated with development pressures and the growing interest of public and private organisations, no PES schemes are currently in place in the Pantanal. Through an exploratory scenario analysis this paper determines the prospects for PES in the area. The findings suggest that a large-scale implementation is unlikely, as this would require much higher levels of environmental awareness among local decision-makers and low substitution rates of ecosystem services by technology. Furthermore, strong socio-economic inequality between inhabitants of the Pantanal lowlands and wealthy farmers of the neighbouring uplands means that potential suppliers of ecosystem services would face very high opportunity costs to participate in PES schemes. The research findings are also relevant to other environmentally sensitive regions experiencing rapid economic growth and weak environmental regulation. 


\section{Biographical sketch page}

Christopher Schulz is a PhD candidate in Geography at the University of Edinburgh, the James Hutton Institute, Aberdeen, and Scotland's Rural College (SRUC), Edinburgh. He holds degrees in Political and Administrative Science from the University of Konstanz (B.A.) and in Environment and Development from the University of Edinburgh (MSc). He is currently researching the value of water in the Brazilian Pantanal as a Scottish Government Hydro Nation scholar: http://www.crew.ac.uk/hydro-nation/scholars

Antonio A. R. Ioris is Lecturer in Environment and Society and director of the MSc in Environment and Development at the University of Edinburgh. He was the general water manager of the Pantanal Programme between 2001 and 2002 (Brazilian Ministry of the Environment), coordinator of the Pantanal International Research Network between 2008 and 2011 and editor of the book Tropical Wetland Management (published in 2012).

Julia Martin-Ortega is Senior Researcher at the James Hutton Institute, Aberdeen, with a background in environmental sciences and economics. She specializes in the relationships between humans/society and water ecosystem services. She leads two work packages of the Scottish Government Research Programme and is involved in projects across Europe, Latin America and Africa.

Klaus Glenk is an environmental economist and leads a research team on ecosystem economics at Scotland's Rural College (SRUC), Edinburgh. He specializes in applied cost-benefit analysis of environmental and agri-environmental policy and has been involved in international research projects within Europe (Germany, UK), in Asia (China, Indonesia), Sub-Saharan Africa and Brazil. 



\section{Prospects for Payments for Ecosystem Services in the Brazilian Pantanal: A Scenario}

\section{Analysis}

\section{Introduction}

Based on the concept of providing economic incentives for improved environmental management, Payments for Ecosystem Services (PES) have become highly popular among scientists and policy-makers as an alternative to command and control mechanisms. Originally, PES were thought of as a transaction between two contracting parties who freely negotiate about payments for specific land management practices that enhance desired ecosystem services to achieve an economically efficient outcome (Engel et al., 2008). For example, the owner of a hydroelectric power plant may pay upstream riparian landowners to conserve the watershed (Blackman \& Woodward, 2010). However, in practice many PES schemes closely resemble government subsidies, as globally governments provide or administer by far the largest sources of funding for PES schemes (Suhardiman et al., 2013). In Costa Rica's national PES programme, for example, landowners are paid to protect forests which provide services related to carbon sequestration, water quality, biodiversity conservation and scenic beauty, but the programme is almost entirely funded through environmental taxes or grants and loans from public international financial institutions (Fletcher \& Breitling, 2012).

Proponents of PES stress its economic efficiency in achieving environmental conservation outcomes and argue that by introducing conditionality and voluntariness it may attract additional funds and produce better results than traditional environmental conservation policies (Wunder, 2005). Others conceive of PES as a viable strategy to achieve both environmental and social objectives, as many PES projects are implemented in rural areas with high levels of poverty (Bulte et al., 2008; Pagiola et al., 2005). Empirical evidence about the potential of PES to contribute to environmental objectives and poverty alleviation simultaneously is mixed, however (Grieg-Gran et al., 2005; Pereira, 2010). 
Corbera et al. (2009) point to the importance of the institutional design, performance, and interplay for the success or failure of PES schemes and highlight the need to achieve a joint understanding of PES projects among multiple actors, especially resource managers. Jack et al. (2008) have stressed the importance of different environmental, socio-economic, and political contexts on the prospects for PES schemes. With regard to water-related PES in Latin America, Martin-Ortega et al. (2013) report that most schemes are typically implemented in a context of general environmental degradation, with deforestation and loss of land cover being the most common threats to water quality. Furthermore, the vast majority of PES schemes operate at the local level as opposed to the national level. In terms of the political context, PES has been categorised as a tool for neoliberalisation and the commodification of nature (e.g. Matulis, 2013), i.e. the expansion of market logic into new spheres (Gómez-Baggethun \& Ruiz-Pérez, 2011).

Considering the above scholarly discussion, the current article focuses on prospects for potential PES schemes in the Brazilian Pantanal, which is the world's largest continental freshwater wetland, but also an area under growing ecological threats given the fast expansion of agro-industrial production, hydropower and urbanisation (Calheiros et al., 2012). PES schemes in the Pantanal may provide opportunities to address tensions between agro-industrial development and environmental conservation in the area. Previous studies have argued for the incorporation of economic arguments into land-use decision making to support environmental conservation in the Pantanal and to balance the effects of economic development (Lourival et al., 2008). Others have called for the development of strategies that transform the value of the Pantanal's ecosystem services into economic benefits for the local population (Seidl \& Moraes, 2000).

The main goal of this article is to evaluate the prospects of a large-scale implementation of PES schemes in the Brazilian Pantanal from a holistic perspective, taking into account a wide range of context factors that can influence prospects for PES. This differs from a large number of 
studies that either discuss impacts of one single factor on the success of PES projects, such as the involvement of local communities in the PES design process (Rawlins \& Westby, 2013), that focus exclusively on land or resource managers in determining prospects for PES (Kosoy et al., 2008) or that concentrate on technical details of PES design (Sattler et al., 2013). For the purposes of this study, we define 'large-scale implementation' as PES becoming the dominant governance instrument for environmental protection in the whole of the Brazilian Pantanal, so that more than $50 \%$ of the Pantanal will be protected. This scale has been selected in response to the enormous attention that PES is currently receiving in the academic and policy sectors, which would be appropriate if PES were to make changes at such a large scale.

The present discussion will also address the official discourse from Brazilian government agencies, which increasingly suggests that PES may evolve into an environmental policy that will make lasting differences on large scales throughout different Brazilian biomes (see e.g. AGEVAP, 2011; Guedes \& Seehusen, 2011 for examples of policy documents or Ioris, 2010 for an overview of recent developments in Brazilian water policy, including PES). PES has become a priority, since the Brazilian government aims to involve the business sector and is trying to adopt market-friendly and non-punitive instruments of environmental management. While there are several studies that extensively discussed the state and future of the Pantanal ecosystem (e.g. Alho \& Sabino, 2011; Bergier, 2013; Calheiros et al., 2012; Junk \& Nunes da Cunha, 2005; Wantzen et al., 2008), the prospects for a large-scale implementation of PES schemes in the area have not yet been the subject of academic investigation. The local relevance of this research question is evident. Additionally, it also serves to better understand the implications of developing PES schemes in the context of very large geographical areas. Furthermore, the article is the first to employ exploratory scenario analysis to assess potential futures of the Pantanal. The value of this approach has been highlighted especially for complex environmental issues at the interface between science, governance and policy (Özkaynak \& Rodríguez-Labajos, 2010). 


\section{The Pantanal and PES in Brazil}

The Pantanal is located in the geographical centre of South America, mainly in the Brazilian states of Mato Grosso and Mato Grosso do Sul, with minor areas in Bolivia and Paraguay. It provides numerous ecosystem services and is an area of high biodiversity (Ioris, 2013). These include hydrological services, such as water purification, groundwater recharging, provision of water, and discharge buffering (Junk \& Nunes da Cunha, 2012). Moreover, it is likely that the Pantanal acts as a net carbon sink, similar to other tropical freshwater wetlands (see e.g. Bernal \& Mitsch, 2013). Local biodiversity is composed of many species that are threatened in neighbouring biomes (Junk et al., 2006) and includes iconic species, such as jaguars and hyacinth macaws. The Pantanal also has high aesthetic and cultural value. Over the course of centuries, the local population, the pantaneiros, have adapted to the unique flood pattern of the Pantanal and developed their own cultural traditions and lifestyle (Girard, 2012). These are centred around low-intensity cattle ranching, which is the dominant economic activity in the sparsely populated and regularly flooded lowlands (Calheiros et al., 2012).

While still in a relatively good ecological state, the services which the Pantanal provides are currently under threat from intensified agriculture, pollution and deforestation in the neighbouring highlands, as well as new dams and hydropower schemes (Alho \& Sabino, 2011; Bergier, 2013; Calheiros et al., 2012; Junk \& Nunes da Cunha, 2005). These have caused major environmental problems, such as large-scale sedimentation in one of the major river basins, the Taquari River, which has left several thousands of $\mathrm{km}^{2}$ of land permanently flooded, causing the displacement of large parts of the local population (Galdino \& Vieira, 2006). Furthermore, urbanisation in the area has significant impacts on water quality (Zeilhofer et al., 2010).

Elsewhere in Brazil, a growing number of PES schemes are being adopted by public agencies and para-governmental entities (such as river basin committees). The national water agency ANA has launched a special programme - 'Water Producer' - aimed at erosion control, forest 
restoration and conservation to improve water quality, which currently supports 15 projects, mostly in the densely populated Southeast of the country (SNIRH, 2013). The Water Producer programme is based on the principle of 'provider-beneficiary' (an extension of the traditional 'polluter-pays principle'), which in practice means compensation to rural landowners for improving water quality and quantity by restoring or preserving grasslands along streams and by implementing best management practices on cropland and cattle ranches (Criado \& Piroli, 2011). The initiative was introduced by ANA and increasingly involves provincial administrations and river basin committees willing to adopt the same management approach. Typically ANA brings expertise; the river basin committee is involved in enforcement and shares the financial cost with public authorities. Some of the better organised river basins in the country are increasingly testing and introducing the Water Producer programme, as the Committee of Rivers Piracicaba, Capivari and Jundiaí, in the Southeast of the country, which established partnerships with national and international organisations to launch PES to farmers in catchments that supply water to the metropolitan region of São Paulo.

Another large PES programme is Proambiente, which aims at enhancing carbon sequestration and biodiversity conservation in the Brazilian Amazon (Hall, 2008). In addition, there is a growing number of initiatives and proposed changes in the legislation aimed at regulating and promoting PES schemes. Those have been enthusiastically endorsed by the Brazilian Ministry of the Environment and other federal and provincial authorities. There are also PES projects at local and municipal levels, mostly dealing with forestry, carbon sequestration and water and land conservation, usually involving a combination of public and private actors (Foleto \& Leite, 2011).

Potential PES schemes in the Pantanal would most likely aim at enhancing water-related ecosystem services, carbon sequestration and storage, as well as biodiversity conservation. ${ }^{\mathrm{i}}$ There already exist PES projects for these services in other parts of Brazil whose model could eventually be followed in the Pantanal (see e.g. Guedes \& Seehusen, 2011). There is still little 
experience in enhancing other important services, such as cultural services, through PES. The main potential suppliers of ecosystem services would be farmers, cattle ranchers and other private landowners. Most potential buyers within PES schemes in the Pantanal could eventually be municipal, state-level and federal Brazilian government entities, as well as international organisations and environmental NGOs.

\section{Exploratory Scenario Analysis}

The prospects for PES in the Pantanal are assessed through the use of exploratory scenario analysis. Scenario analysis is a highly popular method to investigate the potential future consequences of different driving forces on complex systems (Alcamo \& Henrichs, 2008). It is often used for research on environmental issues, including climate change (IPCC, 2000), land use (Van Berkel \& Verburg, 2012), water management (March et al., 2012), and biodiversity (Sala et al., 2000). Scenarios may help policy-makers to understand either possible consequences of their own decisions or potential future contexts in which their policies would apply. It is important to stress that scenario analysis does not aim to predict the future. Rather, scenario analysis describes alternative possible futures that are based on different plausible and internally consistent assumptions (Kosow \& Gaßner, 2008).

Exploratory (or explorative) scenario analysis is one subtype of scenario analysis that aims at describing alternative plausible futures that may be the consequence of different, for example socio-economic, pathways (Börjeson et al., 2006) within what has been termed an 'intuitivelogic model' (Huss \& Honton, 1987; Kahn \& Wiener, 1967). This is opposed to scenarios that are either mere projections of current trends or normative visions of the future (Godet \& Roubelat, 1996; Rounsevell \& Metzger, 2010). The present study applies a qualitative approach, which is common when a limited understanding of causal relationships exists and quantitative modelling is not easily possible (Alcamo \& Henrichs, 2008; Carpenter et al., 2006). Moreover, most qualitative approaches use storylines as a tool for communication (Rounsevell 
\& Metzger, 2010), which in the present case may be used to outline the prospects of PES within plausible future contexts to Brazilian policy-makers. Sometimes, qualitative scenarios are seen as complementary to quantitative scenarios, as for example in the 'story and simulation' approach (Alcamo, 2008). However, as few quantitative data exist for most of the factors discussed in the present study and interrelationships are not straightforward, we have chosen to pursue an entirely narrative and intuitive approach.

\section{Scenario Development Process}

The scenario development process involves identifying "(i) internal and external driving factors acting on the system and (ii) the state of the system resulting from the influence of these driving factors" (March et al., 2012, p. 128). For the present case, a list of 18 drivers of change was compiled (see table 1) which will be discussed individually in the following sections. These driving factors were selected with regard to their potential to have an impact on the prospects for implementation of PES following a review of the current literature on the Pantanal and more broadly (for references see the respective sections). Any factor mentioned in these sources that could be related to PES, even in rather indirect ways, was included in the list of drivers. Intuitive scenario analyses often aim at including the maximum number of factors possible, to account for all possible futures and then filter them according to different characteristics, especially relevance or importance (Kosow \& Gaßner, 2008). These drivers were classified into five categories (social, technological, economic, environmental, and political/governance) to ensure that no relevant factor would be overlooked in the analysis. This classification method is also known as STEEP and is commonly applied in intuitive scenario approaches (Bradfield et al., 2005), as well as in the context of policy, governance and foresight analysis (Schultz, 2006). Prospects for implementation here and in the following sections refers to the probability that policy-makers will adopt PES policies and that landowners will then participate in PES schemes, considering a time horizon of 20-30 years from now. With 'PES', we refer to projects 
that would enhance water-related services, carbon sequestration and storage, or biodiversity, for example through compensating landowners for improved agricultural practices (such as soil conservation techniques that may reduce sedimentation of rivers), maintenance of riparian vegetation or conservation of native forests and vegetation cover.

\section{[INSERT TABLE 1 AROUND HERE]}

This list was validated through consultation with three experts at two different public research organisations in the Pantanal. These experts have worked extensively on socio-ecological issues and environmental conservation within the Pantanal. They were selected to represent different views on PES and have different disciplinary backgrounds, including economics, ecology, and chemistry. There was continued interaction with the experts.

The consultation process followed a semi-structured process with the help of a questionnaire that served as a basis for subsequent discussion and required the experts to judge the importance and uncertainty of every single driver. 'Importance' refers to the degree of impact that these drivers are assumed to have on the prospects for implementation of PES, while 'uncertainty' is related to the predictability of a driver, i.e. the possibility to predict the direction of its future development. Originally, we had the intention to structure the subsequent scenario logic according to the most important and most uncertain drivers, which is a common approach in scenario analysis (Kosow \& Gaßner, 2008; Schwartz, 1991). However, the expert opinions on these two properties of the individual drivers differed significantly. Nevertheless, the responses provided crucial insights that will be commented in greater depth when explaining the scenario logic. As part of the validation process, experts were asked to point out additional drivers that might be missing, however, only one mentioned "farmers and municipalities of the surrounding plateau". This was not included as an additional driver as these actors are included directly 
under the driver 'economic competitiveness of lowland farmers vs. highland farmers', as well as indirectly under 'pollution with chemicals and sediments' and a few other drivers.

Lastly, the questionnaire asked the experts to evaluate the direction of the impact of a driver on the prospects for implementation of PES ('positive', 'negative' or 'ambiguous/unclear'), i.e. what change in the prospects for PES could be expected as a consequence of the presence or increase of a particular driver of change. The intention here was to validate assumptions about the effects of drivers on PES that are discussed in detail in the following sections. Since the effects of many of these drivers have not been previously discussed explicitly in the literature, it was often necessary to propose assumptions based on our own judgement, thus introducing new hypotheses that will have to be further investigated in the future. Due to the limited evidence base, we do not claim that all our assumptions may hold in the future, but at the same time, we believe that it is important to start the discussion.

The expert opinions again revealed strong disagreement on the role and development of the different drivers. Such disagreement is fairly common in scenario development processes (see e.g. Carpenter et al., 2006) due to the inherent uncertainty surrounding different drivers, which justifies the performance of a scenario analysis in the first place. Moreover, ideological differences and different disciplinary backgrounds may explain some divergences in judgements, for example with regard to the effect of increased economic development on environmental policies and PES in particular. Nevertheless, certain patterns emerged that were used for the development of the scenario logic.

\section{Social Drivers of Change}

Rural population growth, including by migration, is expected to have a negative impact on the likelihood that PES will be implemented in the future. Population growth could plausibly mean that more people would need to be involved in PES schemes, which in turn would increase transaction costs of such schemes. As the cost for PES increases, it becomes less attractive for 
investors. This reasoning coincides with the findings of Sandker et al. (2012), who state that PES works better where population densities are low. Moreover, population growth increases the opportunity costs for PES projects, since there is a higher demand for agricultural products (Sandker et al., 2010). However, population growth may interact with other drivers of change (see e.g. Heath \& Binswanger, 1996) such as environmental awareness, social inequality, the prevalence of traditional knowledge or land-use change, which means that under certain circumstances it may have different effects to the ones assumed here. This could be the case if population growth is accompanied by a strong increase in environmental awareness, for example.

Environmental awareness of decision-makers and the general public in the area is hypothesised to have a positive impact on PES in the Pantanal. This needs to be justified as PES is not universally welcomed by environmentalists (see e.g. McCauley, 2006; Redford \& Adams, 2009) or those who express concern over the 'commodification of nature' (e.g. Kosoy \& Corbera, 2010). However, in the Pantanal, $95 \%$ of land is privately owned and $80 \%$ is used for cattle ranching (Seidl et al., 2001); it thus seems plausible that most landowners aim at generating income from their land. In the future, PES may therefore be seen as a more environmentally friendly income-generating land use alternative to cattle ranching, as both traditional and modern cattle ranching practices have been identified as unsustainable from a long-term perspective (Ioris, 2012). This would of course also depend on the amount of money to be paid.

Social inequality, understood as the concentration of social, economic, and political power, as well as land ownership in fewer hands, is difficult to assess in terms of its effects on the prospects for PES implementation. Nonetheless, regional development in the Paraguay River Basin and around the Centre-West region of Brazil has traditionally been shaped according to the interests of a small economic elite, which is dominated by agribusiness groups. These have used their political influence to systematically contain the regulatory impact of state and federal 
environmental agencies, particularly since the 1990s (see Ioris, 2012). In this context, it is plausible that innovative schemes, such as PES, will only be adopted and effectively promoted if they correspond to the expectations of the stronger politico-economic sectors. Likewise, more dynamic members of the agribusiness community may perceive PES as an opportunity to improve their environmental credentials and minimise their negative image in the national and international media. Examples of 'greenwashing' have been observed in the advertising material printed by the Mato Grosso state administration, using the biodiversity of the Amazon Forest and the Pantanal to claim some (questionable) commitment to environmental conservation (Ioris, 2013). Comparable mechanisms of political appropriation of ecological modernisation instruments are also common in other parts of Brazil, which means that PES is becoming an important element of the consolidation of an agenda of conservative environmental management reforms (Eloy et al., 2013).

The prevalence of traditional pantaneiro culture may have a negative impact on the prospects for PES implementation. In the past, novel policies from outside, such as a certification scheme for local beef, met little interest among traditional farmers in the Pantanal (Charnoz, 2010; Wantzen et al., 2008) and a traditional mind-set is commonly associated with reduced openness to change (Schwartz, 1996). However, some researchers argue that traditional pantaneiro culture is based on sustainable and environmentally friendly land management techniques and that the Pantanal is a cultural landscape that depends on these (Junk \& Nunes da Cunha, 2012), although their sustainability has been questioned (Ioris, 2012). In the unlikely case that PES schemes compensated farmers for basically unchanged farming practices, one might assume a positive impact of this factor for PES.

\section{Technological Drivers of Change}

A more widespread application of modern agricultural technology is assumed to have a negative impact on the prospects for PES implementation. As technology increases the efficiency of 
agricultural activities, these become much more profitable, which translates into increasing opportunity costs of participating in PES. Yet, it could be argued that higher yields per area also mean that farmers would have more land available for land-diversion PES schemes, where some land is set aside for 'nature' to provide ecosystem services (Zilberman et al., 2008). However, following the current economic model, it seems much more likely that farmers would prefer to maximise revenue by making use of all available land for agriculture without environmental restrictions (Ferreira \& Rossetto, 2010).

Water management technology is a factor especially relevant in the context of hydroelectric power generation, but its impact on the prospects for implementation of PES is not entirely clear. Payments from the owners of hydroelectric power dams to upstream riparian landowners for improved land management techniques are a typical example of PES (Blackman \& Woodward, 2010; Engel et al., 2008). However, in the case of the Pantanal, hydroelectric power dams are located upstream in the neighbouring uplands and affect the flood pulse in the downstream wetland with negative effects on biodiversity (Calheiros et al., 2012). An increase in the number of such dams would thus enhance the potential for PES schemes, but only in the uplands. Farmers could be paid by hydroelectric power companies to reduce sediment runoff from their fields. Nevertheless, this would be a challenging task given the vast dimensions of the area and that farming in the uplands is highly profitable (Ioris, 2012).

Monitoring technology is used to control and quantify changes in ecosystem service provision, e.g. to detect vegetation cover changes by remote sensing devices (Gibbs et al., 2007). A more widespread use of these technologies and progress in their effectiveness is thus expected to have a positive effect on the prospects for PES implementation as ecosystem service 'buyers' receive evidence about the actual delivery of services (Alston et al., 2013). This increased transparency in turn would help to justify the use of funds for PES projects, by local, national, and international ecosystem service buyers (Porras et al., 2013). 


\section{Economic Drivers of Change}

The impact of general economic development in the Pantanal on the prospects for implementation of PES is difficult to predict. One could hypothesise that economic development increases the chances for PES as more funds would become available in the local economy for potential use in PES projects. Yet, interactions with many other factors need to be considered. For example, economic development may increase the use of technology across all sectors (Perez-Carmona, 2013), may change attitudes towards the environment (McConnell, 1997), or may change political priorities (Inglehart, 1997).

If national and world market prices of key commodities of the area such as beef, soybean, and cotton rise, this will evidently have a negative effect on the prospects for implementation of PES schemes. Opportunity costs for those considering investments in PES locally would increase significantly as farming and agriculture become more attractive. The strong influence of commodity prices on land values in the Pantanal has been documented well by Lourival et al. (2008).

The economic competitiveness of often very traditional lowland farmers in comparison with their much more 'modern' counterparts in the uplands is another factor that has been discussed in the literature on ecosystem services in the Pantanal (Wantzen et al., 2008). It is hypothesised here that a reduced competitiveness of lowland farmers would have a positive effect on the prospects for implementation of PES. On the one hand, PES works best where opportunity costs for service providers are low (Wunder, 2005). On the other hand, economic necessity may force lowland farmers to consider new income strategies, such as PES, although the presence of enabling governance structures, such as e.g. NGOs would be needed as well (Martin-Ortega et al., 2013).

Environmental Drivers of Change 
Climate change could have an indirect positive effect on the prospects for implementation of PES, despite its negative effects on the local environment. In the Pantanal, climate change may affect the natural flood pulse (Junk et al., 2006) and increase the frequency of fires in the dry season which would affect the local vegetation (Junk, 2013). These visible effects could help increase public pressure on policy-makers to act and combat climate change and serve as a justification for new environmental policies, including PES (Ungar, 1995). Furthermore, climate change may increase national and international demand for PES schemes aimed at capturing carbon (Farley et al., 2010). These would be a viable climate change mitigation policy option, as would land-diversion projects to reduce the number of cattle in the area. Methane emissions from cattle ranching are among the highest contributors to the national greenhouse gas emissions of Brazil (Carvalho et al., 2012).

Land-use change could be expected to have an equally positive effect on the prospects for implementation of PES as it provides a justification to act for policy-makers (Ioris, 2010). The reasoning here resembles the previous discussion on the effects on climate change, and is similar for pollution and changes in species composition, which will be discussed further on. As ecosystems of the Pantanal are currently in a relatively good state (Junk \& Nunes da Cunha, 2005; Junk et al., 2006), their degradation through these factors will not result in a complete destruction of the environment within the given time frame of 20-30 years, but merely increase the value of remaining ecosystem services. As their economic value increases through increased scarcity, investments in PES schemes might become more likely.

Increased pollution may have a positive effect on the prospects for implementation of PES as the Pantanal wetland could be seen as a provider of water purification services. However, there might be a tipping point in the future if pollution reaches levels that cannot be abated through natural filtering processes (Junk et al., 2006). Nevertheless, finding buyers for water purification services other than the state would be challenging due to the specific geographic characteristics of the Pantanal. Pollutants mainly originating in farming activities travel from 
the more densely populated and wealthier uplands into the Pantanal (Alho \& Sabino, 2011). This means that those who have the economic means to be potential buyers of ecosystem services do not benefit from water purification taking place in the Pantanal. The sparsely populated lowland areas in turn are socially, economically, and politically marginalised within the states of Mato Grosso and Mato Grosso do Sul and could not easily act as buyers of waterrelated ecosystem services.

Lastly, changes in species composition through the extinction of native species and increased spread of invasive species are supposed to have a positive impact on the prospects for implementation of PES schemes. As argued previously, these would contribute to increased environmental awareness and raise public pressure to adopt new environmental policies. PES projects may also be designed with the objective of eradicating invasive species, which has been successfully tested in South Africa, with significant co-benefits beyond biodiversity protection and ecosystem service provision (Turpie et al., 2008). Furthermore, the presence of invasive species might improve the prospects of international PES projects aimed at conserving biodiversity, e.g. through conservation campaigns of large NGOs, or of PES projects by the Brazilian government in response to international pressure.

\section{Political/Governance Drivers of Change}

There have been and remain many plans to develop large infrastructure projects in the Pantanal, including highways, large hydroelectric power stations and the construction of a navigable waterway (the hidrovia) that would allow year-round commercial shipping and connect Bolivia to international markets (Wantzen et al., 2008). These could have a negative effect on the prospects for implementation of PES schemes. Large infrastructure projects usually cause irreversible disturbances to ecosystem services (Phelan \& Dawes, 2013). But more importantly, by facilitating improved access to remote regions, they raise the economic value of land in the 
Pantanal (Lourival et al., 2008). Consequently, opportunity costs of PES projects would rise, making their implementation less likely.

The creation of a legal framework for PES in turn would evidently have a positive effect on the prospects for its implementation (Greiber, 2009). This could happen either at the federal or state level. However, it would need to be accompanied by effective enforcement as many environmental policies in Brazil are thwarted through corruption and insufficient enforcement (May \& Millikan, 2010).

Increased cooperation between scientists and policy-makers may equally have a positive effect on the prospects for implementation of PES. Wantzen et al. (2008) and Junk and Nunes da Cunha (2012) have both identified deficits in the science-policy interface in the area. As many scientists are very enthusiastic about PES (see e.g. Altmann, 2008), increased cooperation would help in raising awareness for environmental problems among policy-makers and designing potential future PES schemes. More cooperation between the two groups may result from framing PES as a business opportunity, as many policy-makers are closely connected to the commercial farming sector (Safford, 2012).

Finally, if policy-makers emphasise poverty alleviation as one of their political priorities, this would also have a positive impact on the prospects for implementation of PES schemes. If they choose to support PES, they could claim to achieve both environmental and social goals (see e.g. Turpie et al., 2008), even though evidence that PES projects indeed reduce poverty is scarce (Muradian et al., 2010).

\section{Four Future Scenarios for the Pantanal}

After discussing plausible effects of key drivers of change on the prospects for large-scale implementation of PES in the Pantanal, the following sections contain the core elements of the scenario analysis, namely the construction of a scenario logic, the scenario storylines, and their assessment. 


\section{The Scenario Logic}

Narrowing down the complex interrelationships between the factors discussed in the previous sections is a difficult task and necessarily implies a loss of information and detail. For example, not all factors have been considered individually in the following scenario analysis. A conventional strategy to structure complex information is the 'matrix approach' (Schwartz, 1991; van 't Klooster \& van Asselt, 2006), which involves identifying two dimensions along which scenarios can be grouped (Bishop et al., 2007).

An example of the matrix approach are the IPCC's (2000) four 'scenario families' about future emissions that have been formed by employing spatial scale (local vs. global) and policy priorities (environment vs. economy) as structuring dimensions. Usually, the selected dimensions represent the most important, yet most uncertain or unpredictable factors (Schwartz, 1991). However, as mentioned previously, the consultation of local experts on the Pantanal did not result in general agreement on which factors would fall into this category, so a different approach to define the matrix had to be developed in this case.

Notably, all experts agreed that economic factors will be highly relevant for the prospects for implementation of PES and at the same time expected considerable economic development in the Pantanal. There was also a consensus that environmental degradation represents a credible threat to the area. These two factors were classified as 'premises', i.e. very important but relatively predictable factors which thus do not serve as structuring dimensions (Lienert et al., 2006).

However, there is considerable uncertainty about how economic factors and environmental degradation will affect the prospects for implementation of PES. The experts disagreed on the effects of all economic factors and three of four environmental factors, which means that different future scenarios with regard to the relationship between PES and these factors seem to be equally possible. One of the main causes for disagreement on the role of economic 
development for PES might be that this relationship is heavily influenced by intervening variables, especially environmental awareness. Economic development enhances the range of available choices to those who receive higher incomes. Also, it seems reasonable to assume that people with high levels of environmental awareness take different choices than people without them. In the macroeconomic literature, the relationship between economic growth and environmental awareness has been discussed for a long time without reaching a definite conclusion (see e.g. McConnell, 1997), which means that different outcomes are equally plausible. It thus makes sense to use this relationship for a question that serves as one of the structuring dimensions of the matrix:

1) Will economic development go along with higher environmental awareness among decision-makers and the population of the Pantanal?

The second dimension aims at addressing two other central uncertainties. On the one hand, the scale of future environmental degradation in the Pantanal is uncertain but highly relevant for PES. On the other hand, the consulted experts strongly disagreed on the role of technology for PES, which is thus another major driver of uncertainty. The central debate here concerns the extent to which ecosystem services can be and should be replaced by technology (Carpenter et al., 2006). For example, McCauley (2006) argues that PES should be rejected on the grounds that it places nature in competition to technology with regard to its economic efficiency of service provision and fears that future technological progress may cause the gradual replacement of nature by technology. Gómez-Baggethun et al. (2010) point out that differing perceptions on the extent of substitutability of natural resources by technology are one of the main reasons for the divide between the schools of thought known as environmental economics and ecological economics. The second question tries to capture these central divides:

2) To what extent will technology substitute valued ecosystem services that will potentially be lost by environmental degradation? 
The answer to this question depends on several factors from across different categories, including the speed of technological progress, the availability of financial means for a widespread application of technologies, and the intensity of environmental change.

The two questions form two axes in a matrix that range from 'high rate of substitution of ecosystem services by technology' to 'no substitution of ecosystem services by technology' and 'high environmental awareness as a consequence of economic development' to 'no environmental awareness as a consequence of economic development' (see figure 1). This results in four different, plausible, yet idealised scenarios, whose storylines will be subsequently presented. These storylines have been written with the purpose to translate the structuring dimensions and questions into narratives.

\section{[INSERT FIGURE 1 HERE]}

\section{Scenario 1: Business as Usual}

This scenario extrapolates current trends into the future and describes how the Pantanal may develop if policy and general societal trends remain unchanged. The effects of many existing issues are much more pronounced than today with significant impacts on the environment. Economic development has diversified the local economy and increased the average GDP per capita. Economic, social, and political power remain concentrated in the hands of a small elite that cares little about the environmental impacts of their economic activities, although grassroots movements, NGOs, and scientists are trying to raise environmental awareness. While the modernisation and intensification of agricultural techniques has resulted in unsustainable land-use practices directed at short-term profits, their negative effects have not yet undermined the viability of arable agriculture and cattle farming. Much of the biodiversity in the Pantanal is lost, as irreversible changes to the environment have been made to maximise revenue from cattle farming, agriculture, and industrial production. Furthermore, dams and highways have been constructed across the Pantanal. Also, the hidrovia (waterway) has been established to 
facilitate the export of regional products and build transport links to the ports on the Pacific Ocean for increased trade. Due to numerous complexities and lacking support of decisionmakers, PES projects did not materialise on a large scale and could not compete economically with more attractive alternative land uses.

\section{Scenario 2: Ecological Breakdown}

This scenario resembles the 'business-as-usual' scenario in many ways, especially with regard to the absence of environmental awareness and transformation of the economy towards shortterm benefits from intensified agriculture and cattle farming, as well as industrial production. However, in this scenario the impacts on the environment have been devastating with much stronger negative consequences than anticipated by most people. Early warnings of ecologists that many economic activities are in fact unsustainable have been proven to be correct, but remained without appropriate policy responses due to corruption and institutional inertia. Climate change, heavy pollution, the spread of invasive species, large-scale land-use change and modifications of the natural environment have had a strong negative impact on ecosystems and their services to humans. Cattle farming and arable agriculture become economically unviable as intense droughts and enormous floods have destroyed grassland, as well as many former settlements in the area. Water security is strongly compromised through pollution and extreme weather events. Many pantaneiros had to leave their homeland and became environmental refugees. PES is not a viable strategy to solve ecological problems at a large scale as environmental degradation has been so severe that few ecosystem services are left that could be paid for. Overall, technology is not able to substitute the ecosystem services that have been lost.

Scenario 3: Ecosystem Service-Based Economy 
Similar to the 'ecological breakdown' scenario, human capacity to replace ecosystem services with technological solutions has come to its limit. However, as in the 'green technology' scenario, economic development went along with increased environmental awareness among decision-makers and the general population. Policy-makers thus aimed at developing innovative strategies to protect the environment and placed a strong emphasis on ecosystem service-based solutions. In unprecedented societal cooperation, policy-makers and government agencies, private businesses, NGOs, farmers, and other rural landholders collaborate to address environmental challenges. As no technological alternatives to ecosystem services exist or are very costly to implement, payments reach high levels that make the participation in PES projects an attractive alternative to rural landowners who reach higher standards of living. The funding comes from government sources as well as private businesses who have understood that their economic success depends on well-functioning ecosystems. As PES evolves into a viable business model, it outcompetes alternative environmental policies that would not achieve similar impacts on a landscape scale.

\section{Scenario 4: Green Technology}

In this scenario, economic development has increased living standards of the pantaneiros and their neighbours in the highlands. This improvement in living conditions went along with increased environmental awareness among influential decision-makers and the entire population of the area. The combination of increased wealth and higher environmental awareness resulted in large-scale public investments in 'clean' technology, e.g. wastewater treatment plants and renewable energies. While people appreciate and value the natural environment of the Pantanal for aesthetic, moral, and intrinsic reasons, they do not depend on its ecosystem services. In fact, significant transformations have taken place in large parts of the Pantanal which have substantially altered the ecosystem services it provides. For example, there is a large amount of hydroelectric power stations on some of the tributaries, although 
technological improvements have reduced their negative impact on the environment to some extent. The dominant environmental protection strategies are public and private nature reserves. Strategic plans to introduce large-scale PES programmes have been omitted or did not materialise as their implementation proved to be too complicated, and thus share the fate of many other conservation strategies that had been developed over the past decades.

\section{Results: Assessment and Discussion of Scenario Outcomes}

Assessing scenarios may sometimes appear difficult as they are not predictions of the future; it lies in their nature to never be right or wrong. They are often met with considerable scepticism and criticism, especially when reality takes a different path (see e.g. Ehrlich \& Ehrlich, 2009). Another issue with scenario analyses is that it is often difficult to justify the choice of a scenario logic as countless alternatives are available to guide this process (see e.g. Bishop et al., 2007; Börjeson et al., 2006). Therefore, the specific narratives chosen are usually subject to criticism or speculation. However, scenario analysis is precisely aimed at opening up the spectrum of possible futures and stimulating discussion, as is done here. Rounsevell and Metzger (2010: 606) have expressed the purpose of scenario storylines as "to stimulate, provoke, and communicate visions of what the future could hold for us."

The prospects for PES in the Pantanal depend on the future development of the Pantanal, and can be assumed to be low in scenarios 1, 2 and 4, and high in scenario 3. One important finding of the scenario storylines could thus be summarised by stating that despite the enthusiasm and hope that many current publications express for PES, it might not actually work in the area. This is because of many unresolved issues and conceptual weaknesses of PES. Who will voluntarily pay significant amounts of money for the ecosystem services of the Pantanal? Unless threats to human populations and environmental awareness reach unprecedented levels, it is unlikely that landowners of this remote area will be able to attract sufficient funds from ecosystem service buyers. The situation in the Pantanal is further complicated by the fact that 
it is threatened mainly by external actors, e.g. polluting farmers in the neighbouring uplands, who do not experience the negative consequences of their actions. To protect the ecosystem services of the Pantanal, PES schemes would thus really have to tackle areas outside the Pantanal.

Another example of an inherent conceptual weakness of PES schemes has been discussed under the keyword 'permanence' (see e.g. May \& Millikan, 2010). Who would pay farmers to set aside some land as biodiversity reserves, knowing that after the end of the contract these can be converted into agricultural fields if this brings higher revenues? At best, this would be reasonable as a short-term strategy. This problem could only be overcome with very high levels of trust or a very restrictive and well-enforced legal framework, which would thwart the conceptualisation of PES as a voluntary business-like scheme. However, strong resistance from farmers could be expected if legal requirements were to be strictly enforced (Sparovek et al., 2010). At present, compliance with environmental protection laws is low. For example, in the federal state of Mato Grosso, $26 \%$ of Legal Reserves that are legally required to be set aside for conservation are used for agriculture (ibid.: 6050).

It seems that PES can only become a widespread and effective environmental policy under very specific circumstances as described in the scenario "Ecosystem Service-Based Economy". These include the presence of strong environmental threats, the inability to compensate environmental problems by increased use of technology, and advanced cooperation between different groups of society on environmental issues. Otherwise, it is likely that unresolved fundamental issues with PES may prove to be effective obstacles to its large-scale and meaningful implementation. Irrespective of outcomes of ideological debates on PES, its establishment as a dominant environmental policy in the Pantanal appears to be highly uncertain. However, if for unforeseen reasons institutional and other challenges to its implementation can be overcome and significant funds can be mobilised to pay for ecosystem services, then it is likely that it will meet a positive response by landowners in the Pantanal. 
One of the few 'advantages' of the Pantanal with regard to PES is its comparatively strong tenure security as most land is already in private ownership (Seidl et al., 2001).

\section{Conclusion}

Overall, there seems to exist a significant gap between the official discourse on PES, the enormous attention it is currently receiving from scientists and policy-makers, and the real prospects for its large-scale implementation in an area in need for new and effective environmental protection strategies such as the Pantanal. Our exploratory scenario analysis, which is based on an extensive literature review and expert consultation, suggests that this would require the coincidence of (1) high environmental awareness among local policy-makers and general population with (2) low rates of substitution of ecosystem services by technology, possibly caused by strong environmental degradation and change, as described in the storyline of one of four scenarios. In three other scenarios, PES is not expected to gain the momentum needed to become the dominant environmental policy in the Pantanal as either environmental awareness is too low to support an economically unattractive policy or the widespread use of technology means that people do not actually rely on the Pantanal's ecosystem services.

The prospects of PES are further reduced by the specific socio-geographical conditions of the Pantanal, which might hinder government-funded and especially privately organised PES schemes. Potential beneficiaries from the Pantanal lowlands do not have the economic means to be buyers in a PES scheme, while opportunity costs for potential sellers from the agribusiness sector in the uplands continue to rise. This is not to say that PES may not be implemented on small project scales or as a complementary solution in individual cases, possibly involving national and international funders.

On a large scale, however, PES is unlikely to materialize as a solution to halt environmental degradation in the Pantanal also due to one major contradiction: While PES is endorsed by the Brazilian government and others to reconcile economic and business interests with 
environmental protection, major threats to the ecosystems of the Pantanal originate from the powerful economic interests of the agribusiness and industrial sectors. Given the profitability of their activities, not economic incentives of a PES scheme, but only a political solution could ensure an effective protection of the Pantanal in the long term.

One important caveat in the present study were the multiple and complex interrelationships between different drivers of change, which posed some difficulties in the construction of a scenario logic. We have addressed this problem by using different possible relations between drivers as our main uncertainties to structure our scenario analysis, i.e. between economic development and environmental awareness, and environmental degradation and the use of technology, as these were identified as the most relevant factors by the consulted experts. However, more formal and structured alternatives to this intuitive approach exist. Cross-impact balance analysis, for example, explicitly requires experts to make judgements on the interrelationships between different drivers of change and is supported by computers to identify internally consistent scenarios out of large numbers of theoretically possible scenarios arising from the combination of different states of drivers of change (Schweizer \& Kriegler, 2012; Weimer-Jehle, 2006). It may thus be a valuable avenue for future research. Nevertheless, it is important to stress that it is the nature of exploratory scenario analyses to describe plausible and consistent possibilities, not truths. Hence, one of the main objectives of our paper was to contribute to, or rather begin a discussion on the prospects for PES in the Brazilian Pantanal. 


\section{REFERENCES}

AGEVAP (2011): Manual de Orientação ao Proponente de Prestação de Serviços Ambientais, Resende, RJ, Brazil: AGEVAP.

Alcamo, J. (2008): The SAS Approach: Combining Qualitative and Quantitative Knowledge in Environmental Scenarios, in: Alcamo, J. (ed.): Environmental Futures: The Practice of Environmental Scenario Analysis, Amsterdam: Elsevier, 1-11.

Alcamo, J. \& Henrichs, T. (2008): Towards Guidelines for Environmental Scenario Analysis, in: Alcamo, J. (ed.): Environmental Futures: The Practice of Environmental Scenario Analysis, Amsterdam: Elsevier, 13-35.

Alho, C.J.R. \& Sabino, J. (2011): A Conservation Agenda for the Pantanal's Biodiversity, in: Brazilian Journal of Biology, vol. 71(1-suppl): 327-335.

Alston, L.J., Anderson, K., \& Smith, S.M. (2013): Payment for Environmental Services: Hypotheses and Evidence, Working Paper 18740, Cambridge, MA: National Bureau of Economic Research.

Altmann, A. (2008): Pagamento por Serviços Ecológicos: Uma Estratégia para a Restauração e Preservação da Mata Ciliar no Brasil? MSc dissertation, Universidade de Caxias do Sul, RS.

Bergier, I. (2013): Effects of Highland Land-use over Lowlands of the Brazilian Pantanal, in: Science of the Total Environment, vol. 463-464: 1060-1066.

Bernal, B. \& Mitsch, W.J. (2013): Carbon Sequestration in Freshwater Wetlands in Costa Rica and Botswana, in: Biogeochemistry, vol. 115(1-3): 77-93.

Bishop, P., Hines, A., \& Collins, T. (2007): The Current State of Scenario Development: An Overview of Techniques, in: foresight, vol. 9(1): 5-25. 
Blackman, A. \& Woodward, R.T. (2010): User financing in a national payments for environmental services program: Costa Rican hydropower, in: Ecological Economics, vol. 69(8): 1626-1638.

Börjeson, L., Höjer, M., Dreborg, K., Ekvall, T., \& Finnveden, G. (2006): Scenario Types and Techniques: Towards a User's Guide, in: Futures, vol. 38(7): 723-739.

Bradfield, R., Wright, G., Burt, G., Cairns, G., Van der Heijden, K. (2005): The origins and evolution of scenario techniques in long range business planning, in: Futures, vol. 37(8): 795-812.

Bulte, E.H., Lipper, L., Stringer, R., \& Zilberman, D. (2008): Payments for Ecosystem Services and Poverty Reduction: Concepts, Issues, and Empirical Perspectives, in: Environment and Development Economics, vol. 13(3): 245-254.

Calheiros, D.F., Oliveira, M.D., \& Padovani, C.R. (2012): Hydro-ecological Processes and Anthropogenic Impacts on the Ecosystem Services of the Pantanal Wetland, in: Ioris, A.A.R. (ed.): Tropical Wetland Management: The South-American Pantanal and the International Experience, Farnham, UK: Ashgate Publishing, 29-57.

Carpenter, S.R., Bennett, E.M., \& Peterson, G.D. (2006): Scenarios for Ecosystem Services: An Overview, in: Ecology and Society, vol. 11(1): 29.

Carvalho, A.M., César, C.L.G., Fisberg, R.M., \& Marchioni, D.M.L. (2012): Excessive Meat Consumption in Brazil: Diet Quality and Environmental Impacts, in: Public Health Nutrition, vol. 16(10): 1893-1899.

Charnoz, O. (2010): Community Participation in the Pantanal, Brazil. Working Paper No. 93, Paris: AFD.

Corbera, E., González Soberanis, C., \& Brown, K. (2009): Institutional dimensions of 
Payments for Ecosystem Services: An analysis of Mexico’s carbon forestry programme, in: Ecological Economics, vol. 68(3): 743-761.

Criado, R.C. \& Piroli, E.L. (2011): Pagamento por Serviços Ambientais na Gestão dos Recursos Hídricos no Brasil, in: GeoAtos, vol. 11(2): 83-96.

Ehrlich, P.R. \& Ehrlich, A.H. (2009): The Population Bomb Revisited, in: The Electronic Journal of Sustainable Development, vol. 1(3): 5-13.

Eloy, L., Coudel, E., \& Toni, F. (2013): Implementando Pagamentos por Serviços Ambientais no Brasil: caminhos para uma reflexão críticas, in: Sustentabilidade em Debate, vol. 4(1): 21-42.

Engel, S., Pagiola, S., \& Wunder, S. (2008): Designing Payments for Environmental Services in Theory and Practice: An Overview of the Issues, in: Ecological Economics, vol. 65: 663-674.

Farley, J., Aquino, A., Daniels, A., Moulaert, A., Lee, D., and Krause, A. (2010): Global Mechanisms for Sustaining and Enhancing PES Schemes, in: Ecological Economics, vol. 69(11): 2075-2084.

Ferreira, W.N. \& Rossetto, O.C. (2010): As Transformações da Estrutura Fundiária no Pantanal Norte Matogrossense, Anais XVI Encontro Nacional dos Geógrafos, Porto Alegre, RS.

Fletcher, R. \& Breitling, J. (2012): Market mechanism or subsidy in disguise? Governing payment for environmental services in Costa Rica, in: Geoforum, vol. 43(3): 402-411.

Foleto, E.M. \& Leite, M.B. (2011): Perspectivas do Pagamento por Serviços Ambientais e Exemplos de Caso no Brasil, in: Revista de Estudos Ambientais, vol. 13(1): 6-17. 
Galdino, S. \& Vieira, L.M. (2006): A Bacia do Rio Taquari e Seus Problemas Ambientais e Socioeconômicos, in: Galdino, S., Vieira, L.M., \& Pellegrin, L.A. (eds.): Impactos Ambientais e Socioeconômicos na Bacia do Rio Taquari - Pantanal, Corumbá, MS: Embrapa Pantanal.

Gibbs, H.K., Brown, S., Niles, J.O., \& Foley, J.A. (2007): Monitoring and Estimating Tropical Forest Carbon Stocks: Making REDD a Reality, in: Environmental Research Letters, vol. 2: 045023.

Girard, P. (2012): The Pantaneiros, Perceptions and Conflicts about the Environment in the Pantanal, in: Ioris, A.A.R. (ed.): Tropical Wetland Management: The South-American Pantanal and the International Experience, Farnham, UK: Ashgate Publishing, 7-27.

Greiber, T., ed. (2009): Payments for Ecosystem Services: Legal and Institutional Frameworks, Gland, Switzerland: IUCN.

Grieg-Gran, M., Porras, I., \& Wunder, S. (2005): How Can Market Mechanisms for Forest Environmental Services Help the Poor? Preliminary Lessons from Latin America, in: World Development, vol. 33(9): 1511-1527.

Godet, M. \& Roubelat, F. (1996): Creating the future: The use and misuse of scenarios, in: Long Range Planning, vol. 29(2): 164-171.

Gómez-Baggethun, E., de Groot, R., Lomas, P.L., \& Montes, C. (2010): The History of Ecosystem Services in Economic Theory and Practice: From Early Notions to Markets and Payment Schemes, in: Ecological Economics, vol. 69: 1209-1218.

Gómez-Baggethun, E. \& Ruiz-Pérez, M. (2011): Economic Valuation and the Commodification of Ecosystem Services, in: Progress in Physical Geography, vol. 35(5): 613-628. 
Guedes, F.B. \& Seehusen, S.E. (2011): O PSA na Mata Atlântica: Situação Atual, Desafios e Recomendações, in: Guedes, F.B. \& Seehusen, S.E. (eds.): Pagamento por Serviços Ambientais na Mata Atlântica: Lições aprendidas e desafios, Brasília: MMA, 225250.

Hall, A. (2008): Paying for Environmental Services: The Case of Brazilian Amazonia, in: Journal of International Development, vol. 20: 965-981.

Heath, J. \& Binswanger, H. (1996): Natural resource degradation effects of poverty and population growth are largely policy-induced: the case of Colombia, in: Environment and Development Economics, vol. 1(1): 65-84.

Huss, W.R. \& Honton, E.J. (1987): Alternative methods for developing business scenarios, in: Technological Forecasting \& Social Change, vol. 31: 219-238.

Inglehart, R. (1997): Modernization and Postmodernization: Cultural, Economic, and Political Change in 43 Societies, Princeton: Princeton University Press.

Ioris, A.A.R. (2010): The Political Nexus between Water and Economics in Brazil: A Critique of Recent Policy Reforms, in: Review of Radical Political Economics, vol. 42(2): 231250.

— (2012): Reassessing Development: Pantanal's History, Dilemmas and Prospects, in: Ioris, A.A.R. (ed.): Tropical Wetland Management: The South-American Pantanal and the International Experience, Farnham, UK: Ashgate Publishing, 199-222.

— (2013): Rethinking Brazil's Pantanal Wetland: Beyond Narrow Development and Conservation Debates, in: The Journal of Environment \& Development, vol. 22(3): 239-260.

IPCC (2000): Emissions Scenarios: A Special Report of IPCC Working Group III. Summary 
for Policymakers, Geneva: IPCC.

Jack, B.K., Kousky, C., \& Sims, K.R.E. (2008): Designing payments for ecosystem services: Lessons from previous experience with incentive-based mechanisms, in: Proceedings of the National Academy of Sciences, vol. 105(28): 9465-9470.

Junk, W.J. (2013): Current State of Knowledge Regarding South America Wetlands and their Future under Global Climate Change, in: Aquatic Sciences, vol. 75: 113-131.

Junk, W.J. \& Nunes da Cunha, C. (2005): Pantanal: A large South American Wetland at a Crossroads, in: Ecological Engineering, vol. 24: 391-401.

- (2012): Wetland Management Challenges in the South-American Pantanal and the International Experience in: Ioris, A.A.R. (ed.): Tropical Wetland Management: The South-American Pantanal and the International Experience, Farnham, UK: Ashgate Publishing, 315-331.

Junk, W.J., Nunes da Cunha, C., Wantzen, K.M., Petermann, P., Strüssmann, C., Marques, M.I., \& Adis, J. (2006): Biodiversity and its Conservation in the Pantanal of Mato Grosso, Brazil, in: Aquatic Sciences, vol. 68: 278-309.

Kahn, H. \& Wiener, A.J. (1967): The Year 2000: A Framework for Speculation on the Next Thirty-Three Years, New York: The Macmillan Company.

Kosow, H. \& Gaßner, R. (2008): Methods of Future and Scenario Analysis: Overview, Assessment, and Selection Criteria, Studies 39, Bonn: DIE/GDI.

Kosoy, N. \& Corbera, E. (2010): Payments for Ecosystem Services as Commodity Fetishism, in: Ecological Economics, vol. 69: 1228-1236.

Kosoy, N., Corbera, E., \& Brown, K. (2008): Participation in payments for ecosystem 
services: Case studies from the Lacandon rainforest, Mexico, in: Geoforum, vol. 39(6): 2073-2083.

Lienert, J., Monstadt, J., \& Truffer, B. (2006): Future Scenarios for a Sustainable Water Sector: A Case Study from Switzerland, in: Environmental Science \& Technology, vol. 40(2): 436-442.

Lourival, R., Caleman, S.M.Q., Villar, G.I.M., Ribeiro, A.R., \& Elkin, C. (2008): Getting Fourteen for the Price of One! Understanding the Factors that Influence Land Value and how they Affect Biodiversity Conservation in Central Brazil, in: Ecological Economics, vol. 67: 20-31.

Mace, G.M., Norris, K., \& Fitter, A.H. (2012): Biodiversity and Ecosystem Services: A Multilayered Relationship, in: Trends in Ecology \& Evolution, vol. 27(1): 19-26.

March, H., Therond, O., \& Leenhardt, D. (2012): Water Futures: Reviewing Water-scenario Analyses through an Original Interpretative Framework, in: Ecological Economics, vol. 82: 126-137.

Martin-Ortega, J., Ojea, E., \& Roux, C. (2013): Payments for Water Ecosystem Services in Latin America: A Literature Review and Conceptual Model, in: Ecosystem Services, vol. 6: 122-132.

Matulis, B.S. (2013): The Narrowing Gap between Vision and Execution: Neoliberalization of PES in Costa Rica, in: Geoforum, vol. 44: 253-260.

May, P.H. \& Millikan, B. (2010): The Context of REDD+ in Brazil: Drivers, Agents and Institutions. Occasional Paper 55, Bogor, Indonesia: CIFOR.

McCauley, D.J. (2006): Selling out on Nature, in: Nature, vol. 443: 27-28. 
McConnell, K.E. (1997): Income and the Demand for Environmental Quality, in: Environment and Development Economics, vol. 2(4): 383-399.

Muradian, R., Corbera, E., Pascual, U., Kosoy, N., \& May, P.H. (2010): Reconciling Theory and Practice: An Alternative Conceptual Framework for Understanding Payments for Environmental Services, in: Ecological Economics, vol. 69: 1202-1208.

Özkaynak, B. \& Rodríguez-Labajos (2010): Multi-scale Interaction in Local Scenariobuilding: A Methodological Framework, in: Futures, vol. 42: 995-1006.

Pagiola, S., Arcenas, A., \& Platais, G. (2005): Can Payments for Environmental Services Help Reduce Poverty? An Exploration of the Issues and the Evidence to Date from Latin America, in: World Development, vol. 33(2): 237-253.

Pereira, S.N.C. (2010): Payment for Environmental Services in the Amazon Forest: How Can Conservation and Development Be Reconciled?, in: The Journal of Environment \& Development, vol. 19(2): 171-190.

Perez-Carmona, A. (2013): Growth: A Discussion of the Margins of Economic and Ecological Thought, in: Meuleman, L. (ed.): Transgovernance: Advancing Sustainability Governance, Heidelberg: Springer, 83-161.

Phelan, A. \& Dawes, L. (2013): Navigating the social dimension of sustainability decision making of mega-projects, in: Kajewski, S.L., Manley, K., \& Hampson, K. (eds.): Proceedings of the $19^{\text {th }}$ CIB World Building Congress, Brisbane 2013, Queensland University of Technology, Brisbane Convention \& Exhibition Centre, Brisbane, QLD, 229-239.

Porras, I., Aylward, B., \& Dengel, J. (2013): Monitoring Payments for Watershed Services Schemes in Developing Countries, London: IIED. 
Rawlins, M.A. \& Westby, L. (2013): Community participation in payment for ecosystem services design and implementation: An example from Trinidad, in: Ecosystem Services, vol. 6: 117-121.

Redford, K.H. \& Adams, W.M. (2009): Payment for Ecosystem Services and the Challenge of Saving Nature, in: Conservation Biology, vol. 23(4): 785-787.

Rounsevell, M.D.A. \& Metzger, M.J. (2010): Developing Qualitative Scenario Storylines for Environmental Change Assessment, in: Wiley Interdisciplinary Reviews: Climate Change, vol. 1: 606-619.

Safford, T. (2012): Organizational Complexity and Stakeholder Engagement in the Management of the Pantanal Wetland, in: Ioris, A.A.R. (ed.): Tropical Wetland Management: The South-American Pantanal and the International Experience, Farnham, UK: Ashgate Publishing, 173-198.

Sala, O.E., Chapin III., F.S., Armesto, J.J., Berlow, E., Bloomfield, J., Dirzo, R., HuberSanwald, E., Huennecke, L.F., Jackson, R.B., Kinzig, A., Leemans, R., Lodge, D.M., Mooney, H.A., Oesterheld, M., Poff, N.L., Sykes, M.T., Walker, B.H., Walker, M., \& Wall, D.H. (2000): Global Biodiversity Scenarios for the Year 2100, in: Science, vol. 287(5459): 1770-1774.

Sandker, M., Nyame, S.K., Förster, J., Collier, N., Shepherd, G., Yeboah, D., Ezzine-de Blas, D., Machwitz, M., Vaatainen, S., Garedew, E., Etoga, G., Ehringhaus, C., Anati, J., Quarm, O.D.K., \& Campbell, B.M. (2010): REDD payments as incentive for reducing forest loss, in: Conservation Letters, vol. 3: 114-121.

Sandker, M., Ruiz-Pérez, M., \& Campbell, B.M. (2012): Trade-offs between Biodiversity Conservation and Economic Development in Five Tropical Forest Landscapes, in: Environmental Management, vol. 50: 633-644. 
Sattler, C., Trampnau, S., Schomers, S., Meyer, C., \& Matzdorf, C. (2013): Multiclassification of payments for ecosystem services: How do classification characteristics relate to overall PES success?, in: Ecosystem Services, vol. 6: 31-45.

Schomers, S. \& Matzdorf, B. (2013): Payments for Ecosystem Services: A review and Comparison of Developing and Industrialized Countries, in: Ecosystem Services, vol. 6: $16-30$.

Schultz, W.L. (2006): The cultural contradictions of managing change: using horizon scanning in an evidence-based policy context, in: foresight, vol. 8(4): 3-12.

Schwartz, P. (1991): The Art of the Long View: Planning for the Future in an Uncertain World, New York: Doubleday/Currency.

Schwartz, S. (1996): Value Priorities and Behavior: Applying a Theory of Integrated Value Systems, in: Seligman, C., Olson, J.M., Zanna, M.P. (eds.): The Psychology of Values: The Ontario Symposium, Vol. 8, Lawrence Erlbaum Associates, Mahwah, NJ, 1-24.

Schweizer, V.J. \& Kriegler, E. (2012): Improving environmental change research with systematic techniques for qualitative scenarios, in: Environmental Research Letters, vol. 7: 044011.

Seidl, A.F. \& Moraes, A.S. (2000): Global Valuation of Ecosystem Services: Application to the Pantanal da Nhecolandia, Brazil, in: Ecological Economics, vol. 33: 1-6.

Seidl, A.F., Silva, J.S.V., \& Moraes, A.S. (2001): Cattle Ranching and Deforestation in the Brazilian Pantanal, in: Ecological Economics, vol. 36: 413-425.

SNIRH = Sistema Nacional de Informação Sobre Recursos Hídricos (2013): Programa Produtores de Água [webmap], ANA, available online. 
Sparovek, G., Berndes, G., Klug, I.L.F., \& Barretto, A.G.O.P. (2010): Brazilian Agriculture and Environmental Legislation: Status and Future Challenges, in: Environmental Science and Technology, vol. 44(16): 6046-6053.

Suhardiman, D., Wichelns, D., Lestrelin, G., \& Hoanh, C.T. (2013): Payments for ecosystem services in Vietnam: market-based incentives or state control of resources?, in: Ecosystem Services, vol. 6: 64-71.

Turpie, J.K., Marais, C., \& Blignaut, J.N. (2008): The working for water programme: Evolution of a payments for ecosystem services mechanism that addresses both poverty and ecosystem service delivery in South Africa, in: Ecological Economics, vol. 65(4): 788-798.

Ungar, S. (1995): Social scares and global warming: Beyond the Rio Convention, in: Society \& Natural Resources: An International Journal, vol. 8(5): 443-456.

Van Berkel, D.B. \& Verburg, P.H. (2012): Combining exploratory scenarios and participatory backcasting: using an agent-based model in participatory policy design for a multifunctional landscape, in: Landscape Ecology, vol. 27: 641-658.

van 't Klooster, S.A. \& van Asselt, M.B.A. (2006): Practising the scenario-axes technique, in: Futures, vol. 38(1): 15-30.

Wantzen, K.M., Nunes da Cunha, C., Junk, W.J., Girard, P., Rossetto, O.C., Penha, J.M., Couto, E.G., Becker, M., Priante, G., Tomas, W.M., Santos, S.A., Marta, J., Domingos, I., Sonoda, F., Curvo, M., \& Callil, C. (2008): Towards a Sustainable Management Concept for Ecosystem Services of the Pantanal Wetland, in: Ecohydrology \& Hydrobiology, vol. 8(2-4): 115-138.

Weimer-Jehle, W. (2006): Cross-impact balances: A system-theoretical approach to cross- 
impact analysis, in: Technological Forecasting \& Social Change, vol. 73: 334-361.

Wunder, S. (2005): Payments for Environmental Services: Some Nuts and Bolts. Occasional Paper No. 42, Bogor, Indonesia: CIFOR.

Zeilhofer, P., Lima, E.B.N.R., \& Lima, G.A.R. (2010): Land Use Effects on Water Quality in the Urban Agglomeration of Cuiabá and Várzea Grande, Mato Grosso State, Central Brazil, in: Urban Water Journal, vol. 7(3): 173-186.

Zilberman, D., Lipper, L., \& McCarthy, N. (2008): When Could Payments for Environmental Services Benefit the Poor?, in: Environment and Development Economics, vol. 13(3): 255-278. 


\begin{tabular}{|c|c|c|c|c|}
\hline Social & Technological & Economic & Environmental & $\begin{array}{l}\text { Political and } \\
\text { Governance }\end{array}$ \\
\hline $\begin{array}{l}\text { Rural } \\
\text { population } \\
\text { growth (incl. by } \\
\text { migration) }\end{array}$ & $\begin{array}{l}\text { Modern } \\
\text { agricultural } \\
\text { technology and } \\
\text { techniques }\end{array}$ & $\begin{array}{l}\text { General } \\
\text { economic } \\
\text { development in } \\
\text { the Pantanal } \\
\text { area }\end{array}$ & Climate change & $\begin{array}{l}\text { Creation and } \\
\text { support for } \\
\text { large } \\
\text { infrastructure } \\
\text { projects by the } \\
\text { state }\end{array}$ \\
\hline $\begin{array}{l}\text { Environmental } \\
\text { awareness } \\
\text { among } \\
\text { decision-makers } \\
\text { and the general } \\
\text { public }\end{array}$ & $\begin{array}{l}\text { Water } \\
\text { management } \\
\text { technology }\end{array}$ & $\begin{array}{l}\text { World market } \\
\text { prices of key } \\
\text { commodities } \\
\text { (beef, soybean, } \\
\text { cotton) }\end{array}$ & $\begin{array}{l}\text { Land-use } \\
\text { change }\end{array}$ & $\begin{array}{l}\text { Legal } \\
\text { framework for } \\
\text { PES }\end{array}$ \\
\hline $\begin{array}{l}\text { Concentration } \\
\text { of social, } \\
\text { economic, and } \\
\text { political power, } \\
\text { as well as land } \\
\text { ownership }\end{array}$ & $\begin{array}{l}\text { Ecosystem } \\
\text { services } \\
\text { monitoring } \\
\text { technology }\end{array}$ & $\begin{array}{l}\text { Economic } \\
\text { competitiveness } \\
\text { of lowland } \\
\text { farmers vs. } \\
\text { highland } \\
\text { farmers }\end{array}$ & $\begin{array}{l}\text { Pollution with } \\
\text { chemicals and } \\
\text { sediments }\end{array}$ & $\begin{array}{l}\text { Cooperation of } \\
\text { scientists and } \\
\text { policy-makers }\end{array}$ \\
\hline $\begin{array}{l}\text { Prevalence of } \\
\text { traditional } \\
\text { pantaneiro } \\
\text { culture }\end{array}$ & & & $\begin{array}{l}\text { Changes in } \\
\text { species } \\
\text { composition }\end{array}$ & $\begin{array}{l}\text { Poverty } \\
\text { alleviation as an } \\
\text { important } \\
\text { political priority }\end{array}$ \\
\hline
\end{tabular}

Table 1: Key drivers of change influencing the prospects for implementation of PES

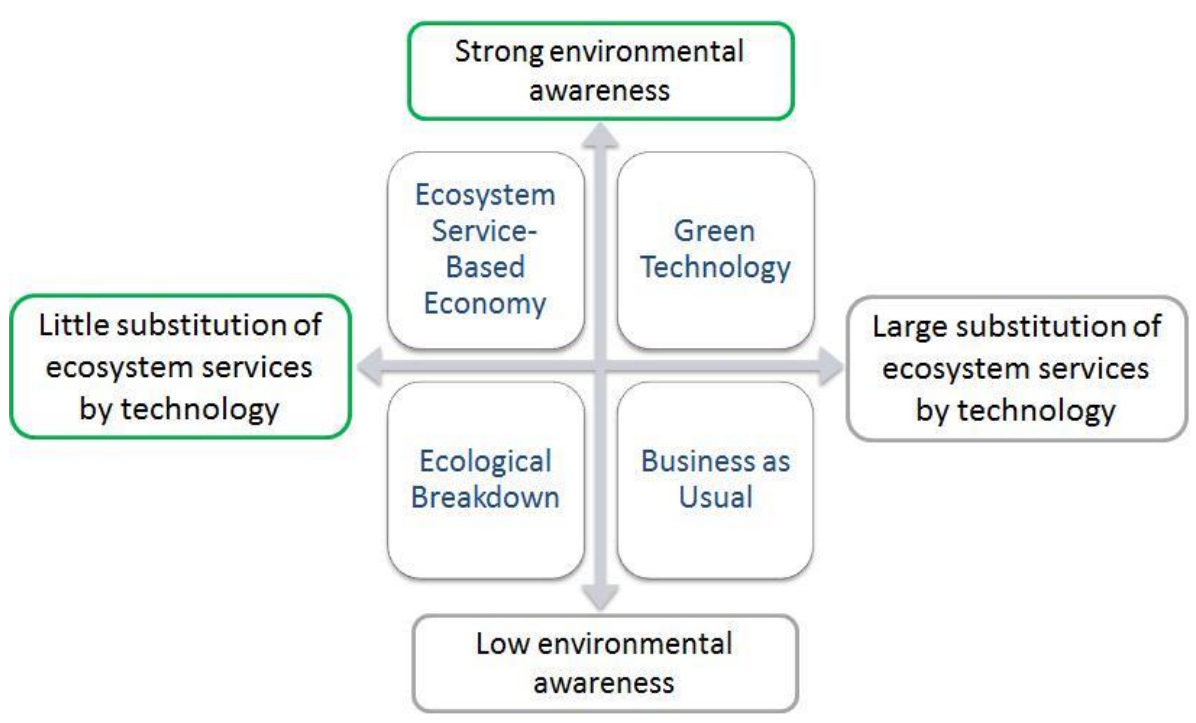

Figure 1: The Scenario Logic - PES in the Brazilian Pantanal 


\section{NOTES}

'Although biodiversity is not an ecosystem service by itself, it is the precondition for most ecosystem services (see Mace et al. (2012) for a good overview). 